Gut, 1977, 18, 208-213

\title{
Relationship between undissociated acidity of gastric juice and gastric protein secreted in response to graded doses of pentagastrin in duodenal ulcer patients
}

\author{
T. POPIELA, ${ }^{1}$ Z. SZAFRAN, HALINA SZAFRAN, AND M. KOMOROWSKA
}

From the Division of Surgical Gastroenterology, Department of Surgery I, and the Department of Clinical Biochemistry, Institute of Paediatrics, Nicholaus Copernicus Medical Academy, Krakow, Poland

SUMMARY Concentrations of free and total hydrogen ions, total protein and pepsin were measured in gastric juice fractions collected during basal secretion and upon stimulation by graded doses of pentagastrin administered intravenously. Undissociated hydrogen ion and non-pepsin protein concentrations were calculated as derived quantities. The studies were carried out in nine patients with duodenal ulcer both before and after truncal vagotomy. It was found that after vagotomy the undissociated hydrogen ion concentration was significantly lower and non-pepsin protein higher than before the operation. No correlation was found between the two quantities both before and after vagotomy. It was concluded that in duodenal ulcer patients either not all non-pepsin protein takes part in buffering of hydrogen ions secreted by parietal cells, or that non-protein buffers play a more important role.

Human gastric juice contains variable amounts of soluble protein, of which a considerable part has no well-defined physiological role. Makhlouf et al. (1970) have suggested that one of the possible functions of non-pepsin protein may be the buffering of hydrogen ions secreted by parietal cells. It is obvious on theoretical grounds that any protein with an isoelectric point higher than the actual $\mathrm{pH}$ of gastric juice will have some buffering capacity. This means that some hydrogen ions will be bound by these proteins when, in the process of secretion, they come into contact with parietal fluid and $\mathrm{pH}$ changes from the relatively high value of the cell interior to the low value of gastric juice. The buffering capacity of such protein will depend on the number of proton-releasing groups with $\mathrm{pK}_{\mathrm{a}}$ values contained within the range covered by the abovementioned $\mathrm{pH}$ extremes.

Makhlouf et al. (1970) found that, in a healthy human subject, undissociated hydrogen ion con-

${ }^{1}$ Address for correspondence: Dr T. Popiela, Division of Surgical Gastroenterology, ul. Pradnicka 37, 31-202 Krakow, Poland.

Received for publication 10 September 1976 centration was correlated with non-pepsin protein secreted upon stimulation with gastrin II or histamine. Our previous studies showed (Szafran et al., 1976) that, in duodenal and gastric ulcer patients, the concentration of undissociated hydrogen ion was positively correlated with total protein in the course of the basal secretion. No such correlation was observed in these patients for gastric juice secreted upon stimulation with a single dose of pentagastrin or histamine.

The aim of the present study was to evaluate the relationship between the secretion of the total, nonpepsin and pepsin protein and undissociated hydrogen ion concentration in the course of intravenous pentagastrin tests with graded doses of the stimulant carried out in duodenal ulcer patients both before and after surgical vagotomy.

\section{Methods}

A group of nine men treated for duodenal ulcer was studied. The mean age of the patients was 36 years (range from 27 to 52 years). Truncal vagotomy with pyloroplasty was applied in all these patients as a basic treatment. Vagotomy was complete in all cases 
as confirmed by the negative results of the insulin test (Popiela et al., 1972). Gastric secretory tests were carried out twice in each patient, first before the operation, and then one to 17 months after vagotomy.

Gastric juice was collected through a gastronasal tube by applying reduced pressure. The stomach was first emptied from the residuum, whereupon three 10 minute fractions of basal secretion were collected. This was followed by the intravenous infusion of pentagastrin solution (Peptavlon, ICI, England) lasting for three hours. The following doses of pentagastrin were applied consecutively: 0.008 , $0.064,0 \cdot 256,1 \cdot 024,2.048$, and $8 \cdot 192 \mu \mathrm{g} / \mathrm{kg} \mathrm{h}$. Each dose was infused during 30 minutes. Eighteen 10 minute fractions were collected during the pentagastrin infusion. Any fraction contaminated with bile was rejected. Dental cotton pledgets inserted into the mouth and frequently changed were used to prevent contamination of gastric juice with saliva. The volume of each fraction was measured, and the fractions were then centrifuged for 20 minutes at $12000 \times g$ in a refrigerated centrifuge.

The $\mathrm{pH}$ of gastric juice fractions was measured by using the Beckman Expandomatic pH-meter supplied with No. 39042 stomach electrode and No. 40249 $\mathrm{Ag} / \mathrm{AgCl}$ reference electrode. Instrument calibration was carried out with $0.1 \mathrm{~mol} / 1$ hydrochloric acid solution (pH 1.1) and $\mathrm{pH} 2.6$ citrate buffer. Free hydrogen ion concentration was calculated from $\mathrm{pH}$ values by using appropriate factors as given by Moore (1968). Total hydrogen ion concentration was measured by the titration with $0.01 \mathrm{~mol} / 1$ $\mathrm{NaOH}$ solution to $\mathrm{pH} 7 \cdot 4$ using the Beckman automatic endpoint titration system. Undissociated hydrogen ion concentration was calculated by subtracting free hydrogen ion concentration from total hydrogen ion concentration.

Protein concentration was determined by the method of Lowry et al. (1951). Bovine albumin (Cohn fraction V, Koch-Light, England) was used as a standard. Pepsin activity was measured by a modification of the Anson method (Rick, 1963). Crystalline pepsin $(2 \times$ cryst. from pig gastric mucosa, Koch-Light, England) was used as a standard. Non-pepsin protein concentration was calculated by subtracting pepsin concentration (as expressed in grams per litre) from total protein concentration.

\section{Results}

The changes in the concentration of total and free hydrogen ions during intravenous infusion of graded doses of pentagastrin in duodenal ulcer patients both before and after vagotomy are shown in Fig. 1. It can be seen that the changes of free acidity are similar to those of total acidity. As might be expected, the values after vagotomy were significantly lower than those before the operation. In patients before vagotomy there was already a definite increase in hydrogen ion concentration in response to the lowest dose of pentagastrin. The peak value was attained in fraction 9, after which there was no further significant change. After vagotomy the response was slower, but the rise of acid concentration lasted longer (up to fraction 15). As the Table

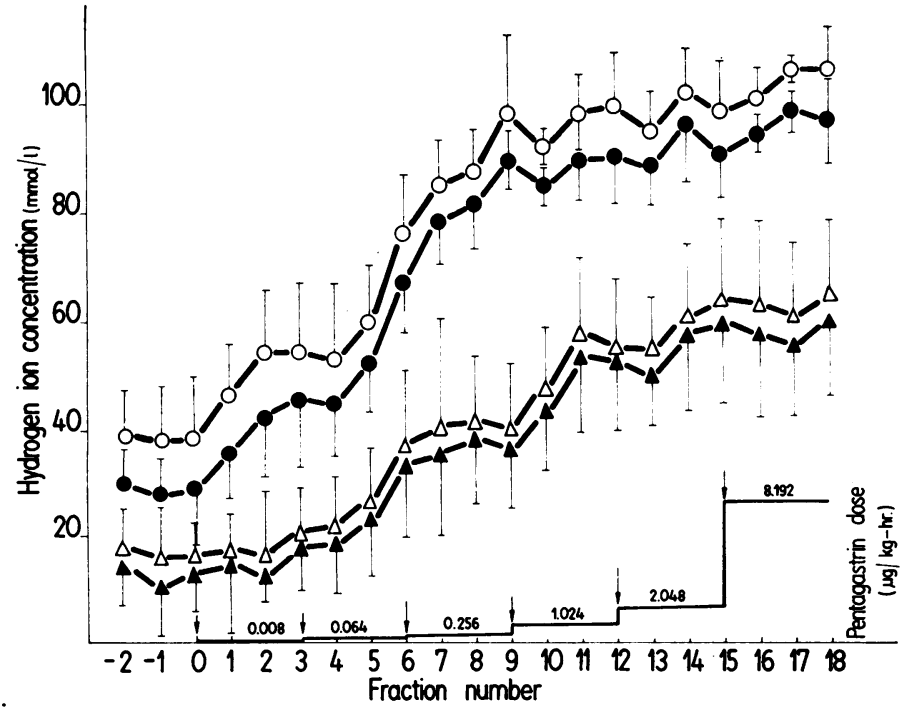

Fig. 1 Changes in free and total hydrogen ion concentration in the course of intravenous pentagastrin test performed in nine patients with duodenal ulcer before and after vagotomy. Fractions $-2,-1$, and 0; basal secretion. Fractions 1 to 18; secretion during pentagastrin infusion. - Free hydrogen ions before vagotomy; $\Delta$ free hydrogen ions after vagotomy; $\bigcirc$ total hydrogen ions before vagotomy; $\triangle$ total hydrogen ions after vagotomy. Mean values $\pm S E M$ are given. 
Table Pentagastrin dose response $\left(D_{50}\right)$ and maximal secretion of hydrogen ions $\left(V_{\max }\right)$ obtained for a group of nine patients with duodenal ulcer before and after vagotomy.

\begin{tabular}{|c|c|c|}
\hline Duodenal ulcer patients & $\begin{array}{c}D_{50} \\
n g / k g \text { min }\end{array}$ & $\underset{\operatorname{mmol} / \min }{V_{\max }}$ \\
\hline $\begin{array}{l}\text { Before vagotomy } \\
\text { After vagotomy }\end{array}$ & $\begin{array}{l}0.62 \pm 0.58^{*} \\
1.28 \pm 1.58^{*}\end{array}$ & $\begin{array}{l}0.65 \pm 0.16^{*} \\
0.19 \pm 0.16^{*}\end{array}$ \\
\hline
\end{tabular}

*The values of $D_{s 0}$ and $V_{\max }$ were obtained by applying Michaelis and Menten kinetics to the secretion of hydrogen ions under the influence of increasing doses of pentagastrin (Petersen and Myren, 1968). Mean values \pm SEM are given.

shows, the dose response to pentagastrin, as expressed by $D_{50}$ value, was $0.62 \mu \mathrm{g} / \mathrm{kg}$ h before the operation and $1.28 \mu \mathrm{g} / \mathrm{kg} \mathrm{h}$ after vagotomy. The corresponding $\mathrm{V}_{\max }$ values for the total hydrogen ions were 0.65 and $0.19 \mathrm{mmol} / \mathrm{min}$ respectively.

The changes of undissociated acidity, representing the difference between total and free hydrogen ion concentrations, are shown in Fig. 2. There was no clear dependence on pentagastrin dose, inasmuch as the changes from fraction to fraction exhibited no definite pattern. On the other hand, there was a clearly visible difference between the values obtained before and after vagotomy. In the latter case the values of undissociated acidity were definitely lower. The differences were statistically significant $(P<$ 0.05 ) for all fractions of basal secretion and for fraction nos. $1,2,3,5,6,8,9,11,12$, and 18 secreted during pentagastrin infusion.

Figures 3 and 4 show the changes in protein concentration, separate curves being displayed for pepsin, non-pepsin, and total protein. Only pepsin protein increases in response to pentagastrin stimulation. Neither total nor non-pepsin protein changed appreciably with the increase in pentagastrin dose. Only a slight tendency to rise was observed after vagotomy. Nevertheless, the values obtained in patients after vagotomy were higher than before vagotomy, both for total and non-pepsin protein. For non-pepsin protein the difference was statistically significant for fraction nos 5, 6, 8, 9-11, and 13-18, and for total protein for fraction nos. 9, 11 , and all the following numbers. This result was rather unexpected in view of the markedly lower values of undissociated acidity observed after vagotomy.

Another striking feature was found when the correlation between undissociated acidity and nonpepsin protein was tested for all fractions of gastric juice obtained during basal secretion and pentagastrin-induced secretion. There was no significant correlation between the two parameters, as reflected by the very low values of correlation coefficient: for basal secretion-0.21 before vagotomy and 0.19 after vagotomy, and for stimulated secretion $0 \cdot 14$ and 0.13 respectively.

\section{Discussion}

The results of this study revealed that, in duodenal ulcer patients, vagotomy brings about marked changes in the undissociated acidity of gastric juice. The observed values were significantly lower after vagotomy than before the operation. At the same time, there was no parallel change in gastric protein concentration. Mean values of total and non-pepsin protein concentrations were higher after vagotomy. It seems logical that, in patients with duodenal ulcer, the parietal component of the

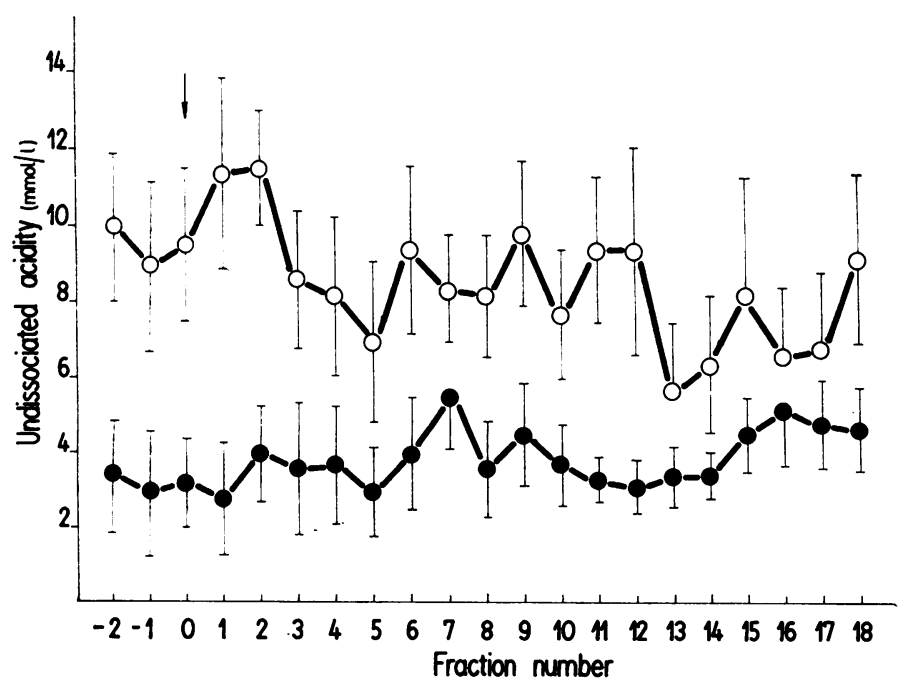

Fig. 2 Changes in undissociated hydrogen ion concentration in the course of intravenous pentagastrin test performed in nine patients with duodenal ulcer before $(\bigcirc)$ and after $(\Theta)$ vagotomy. Mean values $\pm S E M$ are given. Numbering of fractions as in Fig. 1. Beginning of pentagastrin infusion is marked by an arrow. 


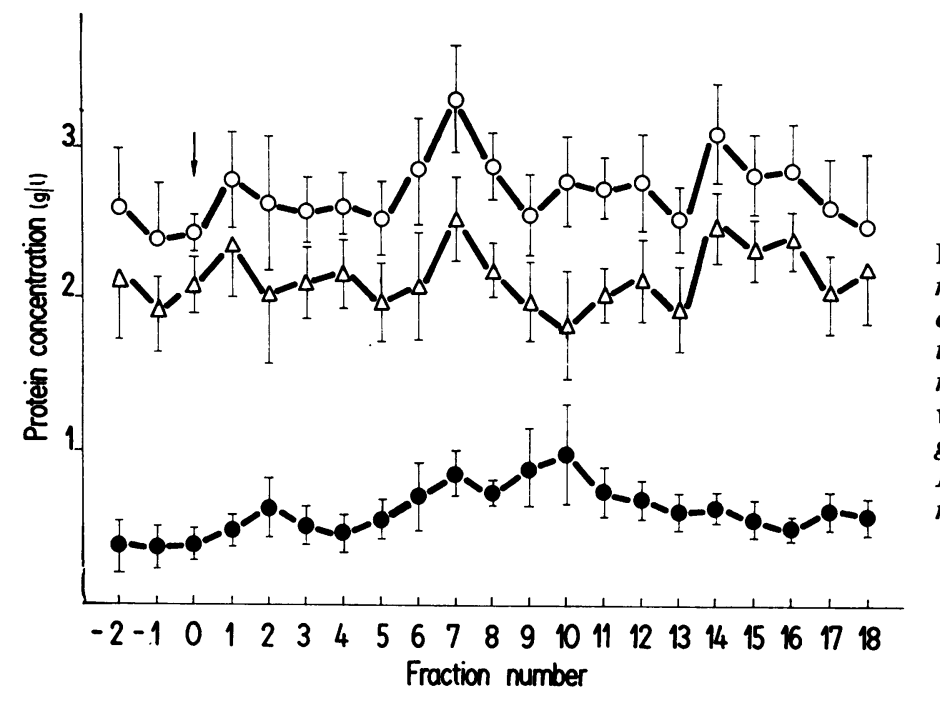

Fig. 3 Changes in total protein $(O)$, non-pepsin protein $(\triangle)$, and pepsin concentration $(\bullet)$ in the course of intravenous pentagastrin test performed in nine duodenal ulcer patients before vagotomy. Mean values \pm SEM are given. Numbering of fractions as in Fig. 1 . Beginning of pentagastrin infusion is marked by an arrow.

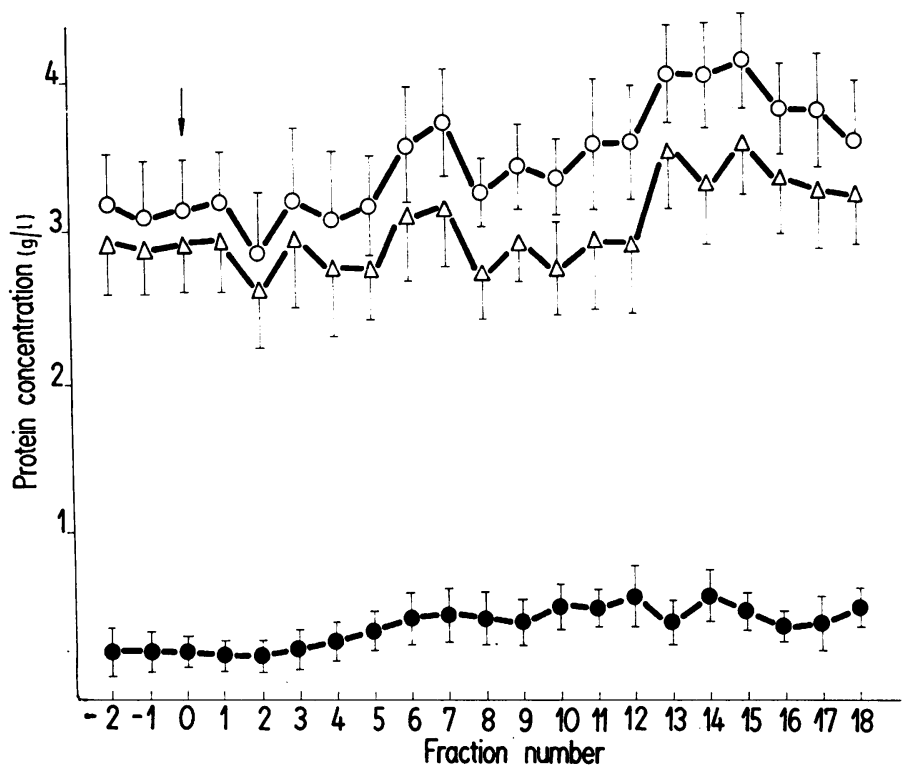

Fig. 4 Changes in total protein $(\bigcirc)$, non-pepsin protein $(\triangle)$, and pepsin concentration $(\circlearrowleft)$ in the course of intravenous pentagastrin test performed in nine duodenal ulcer patients after vagotomy. Mean values $\pm S E M$ are given. Numbering of fractions as in Fig. 1 . Beginning of pentagastrin infusion is marked by an arrow.

secretion should dominate, and thus the concentration of undissociated hydrogen ions should be lower before vagotomy than after it. It is, therefore, difficult to find a satisfactory explanation for the fact that the opposite phenomenon occurs.

No clear effect of pentagastrin dose was observed either on gastric protein or on the undissociated acidity of gastric juice. It is only the concentration of total and free acid, as well as pepsin, that exhibits definite response to pentagastrin infusion. Our results concerning the changes in total hydrogen ion concentration closely resemble those obtained by other authors. The values of $V_{\max }$ and $D_{50}$ (pentagastrin dose response) found for our patients were similar to those obtained by Petersen and Myren (1975) for duodenal ulcer patients. After vagotomy the values of $V_{\max }$ were significantly lower, and $D_{50}$ correspondingly higher than before the operation. 
Makhlouf et al. (1970) found a significant positive correlation between undissociated acidity of gastric juice and non-pepsin protein. These authors suggested that non-pepsin protein is the chief constituent of gastric juice taking part in the buffering of hydrogen ions. Our results are not consistent with this view. There was no significant correlation between undissociated acidity and non-pepsin protein of gastric juice in duodenal ulcer patients both before and after vagotomy in the course of pentagastrin stimulated and basal secretion.

There are many factors which may account for the differing results of the two studies. Makhlouf $e t$ al. (1970) carried out repeated tests in one healthy subject, whereas we have studied a group of duodenal ulcer patients, performing two pentagastrin tests (one before and the other after vagotomy) in each patient. The end-point $\mathrm{pH}$ value of gastric juice titration was also different: 7.4 in our experiments and 8.3 in those of Makhlouf et al. (1970). In addition, these authors used the difference between titratable acidity to $\mathrm{pH} 8.3$ and $\mathrm{pH} 7.0$ as an index of the true undissociated acidity. In fact, Makhlouf et al. (1970) calculated the correlation between the values of this index and protein concentration.

The main argument of Makhlouf et al. (1970) for using $\mathrm{pH} 8 \cdot 3$ as an end point for gastric juice titration was that only at such a $\mathrm{pH}$ is there a balance between the main cations of gastric juice and $\mathrm{Cl}^{-}$ ions. Evidently, it is only at so high a value that all the protons attached to the buffering groups are liberated. In physiological conditions, however, it seems improbable that so high a $\mathrm{pH}$ value obtains at any time during the process of gastric secretion. Evidence is still lacking that the protons backtitrated to $\mathrm{pH} 8.3$ are really 'parietal' protons buffered by gastric proteins or their degradation products in the course of the secretory process.

It is also the mode of stimulant administration that may influence the relation between gastric protein and undissociated acidity. The types of secretory tests were different in the both studies. Inasmuch as protein is secreted by at least two types of gastric mucosal cells (Makhlouf et al., 1968), the different cells may not give the same response to different stimulating agents, and even to different modes of stimulant administration.

The results of our study seem to indicate that in patients with duodenal ulcer either not all nonpepsin protein takes part in buffering of hydrogen ions or non-protein buffers play a more important role. Unfortunately, the individual constituents of non-pepsin protein have not been well characterised. We also have no information on isoelectric points of gastric juice proteins, except for pepsin and intrinsic factor (Fruton, 1971; Marcoullis and Gräsbeck,
1975). Among non-protein buffers, organic acids are present in too low a concentration to be of any importance (Piper et al., 1967), but phosphate with its concentration in gastric juice ranging from $0 \cdot 1$ to 4.0 mmol/l (Burhol et al., 1966) may account for a significant part of buffering capacity of gastric juice constituents. It is also possible that the buffering capacity of the constituents of non-pepsin protein fraction may increase upon peptic degradation. This view may be supported by the studies of Fordtran and Walsh (1973), who found that the buffer capacity of protein food increased by $33 \%$ after incubation with gastric juice. Whereas Roland et al. (1974) observed a lower concentration of pepsin in the gastric juice of vagotomised patients, our results showed no significant change in pepsin concentration after vagotomy. Although we have shown that undissociated acidity and non-pepsin protein are not correlated in patients with duodenal ulcer, we cannot definitely ascribe the buffering to any other specific component of gastric juice.

\section{References}

Burhol, P. G., Myren, J., and Foss, O. P. (1966). Electrolytes in gastric juice of man. I. A statistical analysis of calcium and inorganic phosphorus before and after subcutaneous injection of large doses of histamine. Scandinavian Journal of Clinical and Laboratory Investigation, 18, 325-330.

Fordtran, J. S., and Walsh, J. H. (1973). Gastric acid secretion rate and buffer content of the stomach after eating. Journal of Clinical Investigation, 52, 645-657.

Fruton, J. S. (1971). Pepsin. In The Enzymes, vol. 3, p. 127. Edited by P. D. Boyer. Academic Press: New York.

Lowry, O. H., Rosebrough, N. J., Farr, A. L., and Randall, R. J. (1951). Protein measurement with the Folin phenol reagent. Journal of Biological Chemistry, 193, 265-275.

Makhlouf, G. M., Blum, A. L., and Moore, E. W. (1970). Undissociated acidity of human gastric juice. Measurement and relationship to protein buffers. Gastroenterology, 58, 345-351.

Marcoullis, G., and Gräsbeck, R. (1975). Vitamin B B $_{12}$-binding proteins in human gastric mucosa. Scandinavian Journal of Clinical and Laboratory Investigation, 35, 5-11.

Makhlouf, G. M., Moore, E. W., and Blum, A. L. (1968). Models for the 'secretion' of pepsin and other proteins by the human stomach. Gastroenterology, 55, 457-464.

Moore, E. W. (1968). Determination of $\mathrm{pH}$ by the glass electrode: pH-meter calibration for gastric analysis. Gastroenterology, 54, 501-507.

Petersen, H., and Myren, J. (1975). Pentagastrin doseresponse in peptic ulcer disease. Scandinavian Journal of Gastroenterology, 10, 705-714.

Piper, D. W., Fenton, B. H., and Goodman, L. R. (1967). Lactic, pyruvic, citric and uric acid and urea content of the human gastric juice. Gastroenterology, 53, 42-48.

Popiela, T., Szafran, H., and Szafran, Z. (1972). Evaluation of the completeness of vagotomy in patients with duodenal ulcer based on insulin test and test using! 2-deoxy-Dglucose. (In Polish.) Przeglad Lekarski, 29, 748-755.

Rick, W. (1963). Pepsin, pepsinogen, uropepsinogen. In Methods of Enzymatic Analysis, pp. 819-823. Edited by H. U. Bergmeyer. Chemie: Weinheim. 
Roland, M., Berstad, A., and Liavag, I. (1974). Acid and pepsin secretion in duodenal ulcer patients in response to graded doses of pentagastrin or pentagastrin and carbacholine before and after proximal gastric vagotomy. Scandinavian Journal of Gastroenterology, 9, 511-518.
Szafran, H., Popiela, T., Bucki, J., Lachecki, Z., and Skórzyński, A. (1976). Buffering of hydrogen ions by proteins present in gastric juice of patients with duodenal ulcer. (In Polish.) Przeglad Lekarski, 33, 372-381.

\section{The February 1977 Issue}

\section{THE FEBRUARY 1977 ISSUE CONTAINS THE FOLLOWING PAPERS}

24-hour intragastric acidity and nocturnal acid secretion in patients with duodenal ulcer during oral administration of cimetidine and atropine R. E. POUNDER, R. H. HUNT, S. H. VINCENT, G. J. MILTON-THOMPSON, AND J. J. MISIEWICZ

Morphological and pharmacological study of the parietal cells of the stomach in the dog during periods of maximal acid output and after the gastric secretory inhibitor UK-9040 D. B. HAMER, A. B. PRICE, AND J. H. BARON

Effect of cimetidine on the human lower oesophageal sphincter D. H. OSBORNE, J. LENNON, M. HENDERSON, G. LIDGARD, R. CREEL, AND D. C. CARTER

Effect of fundic distension on gastric acid secretion in man U. GRÖTZINGER, S. BERGEGÅRDH, AND L. OLBE

Effects of oral calcium gluconate on gastric acid secretion and serum gastrin concentration in man M. J. BRODIE, P. C. GANGULI, A. FINE, AND T. J. THOMSON

Crohn's disease of the duodenum F. WARREN NUGENT, M. RICHMOND, AND S. K. PARK

Lowering of fasting and food stimulated serum immunoreactive gastric inhibitory polypeptide (GIP) by glucagon R. EBERT, R. ARNOLD, AND W. CREUTZFELDT
Comparative study of the value of the calcium, secretin, and meal stimulated increase in serum gastrin to the diagnosis of the Zollinger-Ellison syndrome C. B. H. LAMBERS AND J. H. M. VAN TONGEREN

Human intestinal ion transport in vitro G. $\mathbf{L}$. CORBETT, P. E. T. ISAACS, A. K. RILEY, AND L. A. TURNBERG

Relationship between changes in intraluminal pressure and transmural potential difference in the human and canine jejunum in vivo N. W. READ, R. H. SMALLWOOD, R. J. LEVIN, C. D. HOLDSWORTH, AND B. H. BROWN

Whipple's disease with minimal intestinal involvement S. MOORTHY, G. NOLLEY, AND J. A. HERMOS

Transmission of rotavirus gastroenteritis from children to a monkey J. D. MITCHELL, L. A. LAMBETH, L. SOSULA, A. MURPHY, AND M. ALBREY

Ultrasound and jaundice F. R. VICARY, G. CUSICK, I. M. SHIRLEY, AND R. J. BLACKWELL

Medical Research Council and Health Departments-Joint statement of policy for biomedical research: gastroenterology

Notes and activities

Books

Copies are still available and may be obtained from the PUBLISHING MANAGER, BRITISH MEDICAL ASSOCIATION, TAVISTOCK SQUARE, LONDON WC1H 9JR, price $£ 2 \cdot 75$, including postage 